\title{
Preparation of Ceria-Zirconia Mixed Oxide by Hydrothermal Synthesis
}

\author{
Siti Machmudah ${ }^{1}$, M. Akmal Hadian ${ }^{1}$, Lenno Samodro K. ${ }^{1}$, Sugeng Winardi ${ }^{1}$, Wahyudiono ${ }^{2}$, Hideki Kanda ${ }^{2} \&$ \\ Motonobu Goto ${ }^{2}$ \\ ${ }^{1}$ Department of Chemical Engineering, Sepuluh Nopember Institute of Technology, Indonesia \\ ${ }^{2}$ Department of Chemical Engineering, Nagoya University, Nagoya 464-8063, Japan \\ Correspondence: Siti Machmudah, Department of Chemical Engineering, Sepuluh Nopember Institute of \\ Technology, Surabaya, 60111, Indonesia. E-mail: machmudah@chem-eng.its.ac.id
}

Received: May 4, 2015

Accepted: June 5, 2015

Online Published: June 30, 2015

doi:10.5539/mas.v9n7p134

URL: http://dx.doi.org/10.5539/mas.v9n7p134

\begin{abstract}
Ceria-zirconia mixed oxides have been synthesized by hydrothermal synthesis process. Under hydrothermal conditions, water potential to control the direction of crystal growth, morphology, particle size and size distribution, because of the controllability of thermodynamics and transport properties by pressure and temperature. The synthesis was carried out at temperatures of $150-200{ }^{\circ} \mathrm{C}$ and pressure of $5 \mathrm{MPa}$ in a batch reactor. The reactor made of SUS 304 tube reactor with internal volume of $8.8 \mathrm{ml}$. The synthesized products were calcined and characterized using SEM, XRD and FTIR. The results showed that the particles formed were sphere shaped particles with smooth morphology and the size of particle diameters were 35,61 , and $31 \mathrm{~nm}$ on average for reactions temperatures of 150,180 , and $200^{\circ} \mathrm{C}$, respectively. The XRD pattern indicated that ceria-zirconia mixed powder was uniformly distributed in the structure to form a homogeneous solid solution.
\end{abstract}

Keywords: hydrothermal, synthesis, ceria-zirconia oxide, particles, composite

\section{Introduction}

In recent years, with the increasing awareness of both environmental safety and the need for optimal energy utilization, there is a case for the development of nonhazardous materials. These materials should not only be compatible with human life but also with other living forms or species. Moreover, processing techniques such as fabrication, treatment, reuse, and recycling of waste materials should be environmentally friendly. In this respect, the hydrothermal method occupies a unique place in modern science and technology. In the last decade, the hydrothermal method has offered several new advantages, suchas homogeneous precipitation using metal chelates under hydrothermal conditions, decomposition of hazardous or refractory chemical substances, monomerization of high polymers, and a host of other environmental engineering and chemical engineering issues dealing with recycling of rubbers and plastics, and so on. The solvation properties of supercritical solvents are being extensively used for detoxifying organic and pharmaceutical wastes and also to replace toxic solvents commonly used for chemical synthesis (Bryappa \& Yoshimura, 2001).

Recently, cerium oxide $\left(\mathrm{CeO}_{2}\right)$ has receivedincreased attention in various fields because of its unique redox properties, high oxygen mobility and forming solid solutions with other metal oxides easily (Lee et al., 2011). In wide applications, $\mathrm{CeO}_{2}$ was a technologically important material to promote three-way catalysts for the elimination of toxic auto-exhaust gases, low-temperature water-gas shift reaction, oxygen sensors, oxygen permeation membrane systems, fuel cells, glass-polishing materials, ultraviolet absorbent, as well as biotechnology, environmental chemistry, and medicine (Sun et al., 2012; Wang et al., 2010; Yu et al., 2010; Yuan et al., 2010). Neto and Schmal (Neto and Schmal 2013) reported that as catalysts, the $\mathrm{CeO}_{2}$-based materials have been used for several reactions. The higher performance of $\mathrm{CeO}_{2}$ is assigned to the redox property $\left(\mathrm{Ce}^{4+} \leftrightarrow \mathrm{Ce}^{3+}\right)$ promoting oxygen vacancies in the lattice, which are responsible for the high oxygen atom mobility. This is one of the important characteristics of ceria, allowing fluctuation between oxidant and reductant conditions due to the oxygen storage capability in the lattice structure. The major drawback of an oxygen storage system based on pure $\mathrm{CeO}_{2}$ is poorly thermostable and easily lose oxygen buffer capacity under high temperatures ( $\mathrm{Zhu}$ and $\mathrm{He}$ 2008). 
In this work, $\mathrm{CeO}_{2}$ would be synthesized with zirconia $\left(\mathrm{ZrO}_{2}\right)$ to increase its thermal stability and oxygen storage capacity by using hydrothermal treatment. The hydrothermalmethod was considered as asimple and powerful routes and, recently, become more popular in producing ordered nano array structures of materials. This method relies on the chemical reactions and solubility changes of substances in a sealed heated aqueous solution above ambient temperature and pressure to grow nanocrystals (Yang et al., 2013). Raju et al., (Raju et al., 2009)explained that the powder product from synthesized ceria-zirconia had good thermal stability and structural integrity even after repeated redox cycles at $700^{\circ} \mathrm{C}$. They also found that the oxygen storage capacity has a strong dependence on surface area for ceria-zirconia but for high surface area oxides, the amount of exchangeable oxygen is limited by the intrinsic reducibility of the material. Abdollahzadeh-Ghom et al., (Abdollahzadeh-Ghom et al., 2011) also stated that the combination of ceria-zirconia enhances drastically its oxygen storage capacity. Furthermore, in this study the thermal stability and the oxygen storage capacity of powder products were not conducted. Since temperature dependence on the characteristic of ceria-zirconia mixed oxide powder has not been investigated in detail, the effect of synthesis temperature on the morphology and crystallinity of ceria-zirconia oxide particles was investigated in this work.

\section{Method}

\subsection{Materials}

Cerium (III) nitrat hexahydrate $\left(\mathrm{Ce}\left(\mathrm{NO}_{3}\right)_{3} \cdot 6 \mathrm{H}_{2} \mathrm{O}\right)$ and zirconium nitrate oxide dehydrate $\left(\mathrm{ZrO}\left(\mathrm{NO}_{3}\right)_{2} \cdot 2 \mathrm{H}_{2} \mathrm{O}\right)$ were obtained from chemicals suppliers, Wako Pure Chemical Industries Ltd. (Japan) and Kanto Chemical Co. Inc. (Japan), respectively, with the purities of more than $98.0 \%$. Cerium and zirconium solution with concentration of 0.1 and $0.3 \mathrm{M}$, respectively, were prepared by dissolve in deionized water. Then, the solutions were mixed in the flask with a Ce:Zr mole ratio of 1:15. Furthermore, the mixed solution was used in all experiments.

\subsection{Experiment}

Experiments were conducted using a SUS 304 tube reactor (AKICO Co., Ltd., Japan; with internal volume 8.8 $\mathrm{ml}, 12.0 \mathrm{~mm}$ i.d.; $7.8 \mathrm{~mm}$ in length) at temperatures of $150-200^{\circ} \mathrm{C}$ and pressure of $5 \mathrm{MPa}$. The reactor was filled with 7.5-8.0 g of solution corresponding to $0.8-0.9 \mathrm{~g} . \mathrm{cm}^{-3}$ water density. The reactor was loaded into an electric furnace (Linn High Therm GmbH, model VMK 1600) and quickly heated to the desired temperature. After a given reaction time $18 \mathrm{~h}$, the reactor was taken out from the electric furnace and quickly quenched in a water bath at atmospheric conditions. After cooling, the reactor was opened and then liquid and solid fractions were collected with washing inside the reactor by $10 \mathrm{ml}$ of water. The products were dried in the oven at $60^{\circ} \mathrm{C}$ for $6 \mathrm{~h}$ and then weighed. Finally, each products were calcined at $900^{\circ} \mathrm{C}$ for $6 \mathrm{~h}$. After the process, the calcined products were stored in desiccator at room temperature until next characterization.

The morphologies of the calcined powder products were observed using a scanning electron microscope (SEM; JEOL JSM-6390LV). The particle diameters were determined from the SEM image using image analyzer software (Image J 1.42). Transmission electron microscopy (TEM) was performed in ultra-high resolution analytical electron microscope JEOL 3010. Prior to characterize, the calcined powder products were dispersed in ethanol through sonication (Us CLeaner, US-1R, AsOne) and then drop casted on an elastic carbon-coated copper grid. X-ray diffraction (XRD) patterns were determined to confirm that the crystal structure of ceria-zirconia was formed via this synthesis method. A Rigaku RINT 2100/PC XRD machine (40 kV and 200 $\mathrm{mA}$ ) equipped with a $\theta-\theta$ wide-angle goniometer and scintillation detector was used for all XRD measurements, using $\mathrm{Cu} \mathrm{K \alpha}$ radiation $(\lambda=1.5406 \AA)$. The Spectrum One FT-IR spectrophotometer (Perkin-Elmer, Ltd., England) was carried out to determine the structure of the crystal structure of ceria-zirconia after hydrothermal treatment. The spectra were measured in ATR (attenuated total reflectance) mode (golden single reflection ATR system, P/N 10500 series, Specac) at $4 \mathrm{~cm}^{-1}$ resolution. The scanning wavenumber ranged from 4000 to 650 $\mathrm{cm}^{-1}$.

\section{Results}

Figure 1 shows the SEM images of calcined powder particle from $\mathrm{Ce}\left(\mathrm{NO}_{3}\right)_{3}$ and $\left(\mathrm{ZrO}\left(\mathrm{NO}_{3}\right)_{2}\right.$ mixed oxides after hydrothermal synthesis for $18 \mathrm{~h}$. These SEM images described regular sphere shaped particles having smooth surface morphology, except in Figure 1(b). Due to the SEM image resolution, the morphology of particles formed at $180^{\circ} \mathrm{C}$ seemed less clear. However, based on Figures 1(a) and 1(c), it could be said that the particles formed at $180^{\circ} \mathrm{C}$ were also sphere shaped particles with smooth morphology. 

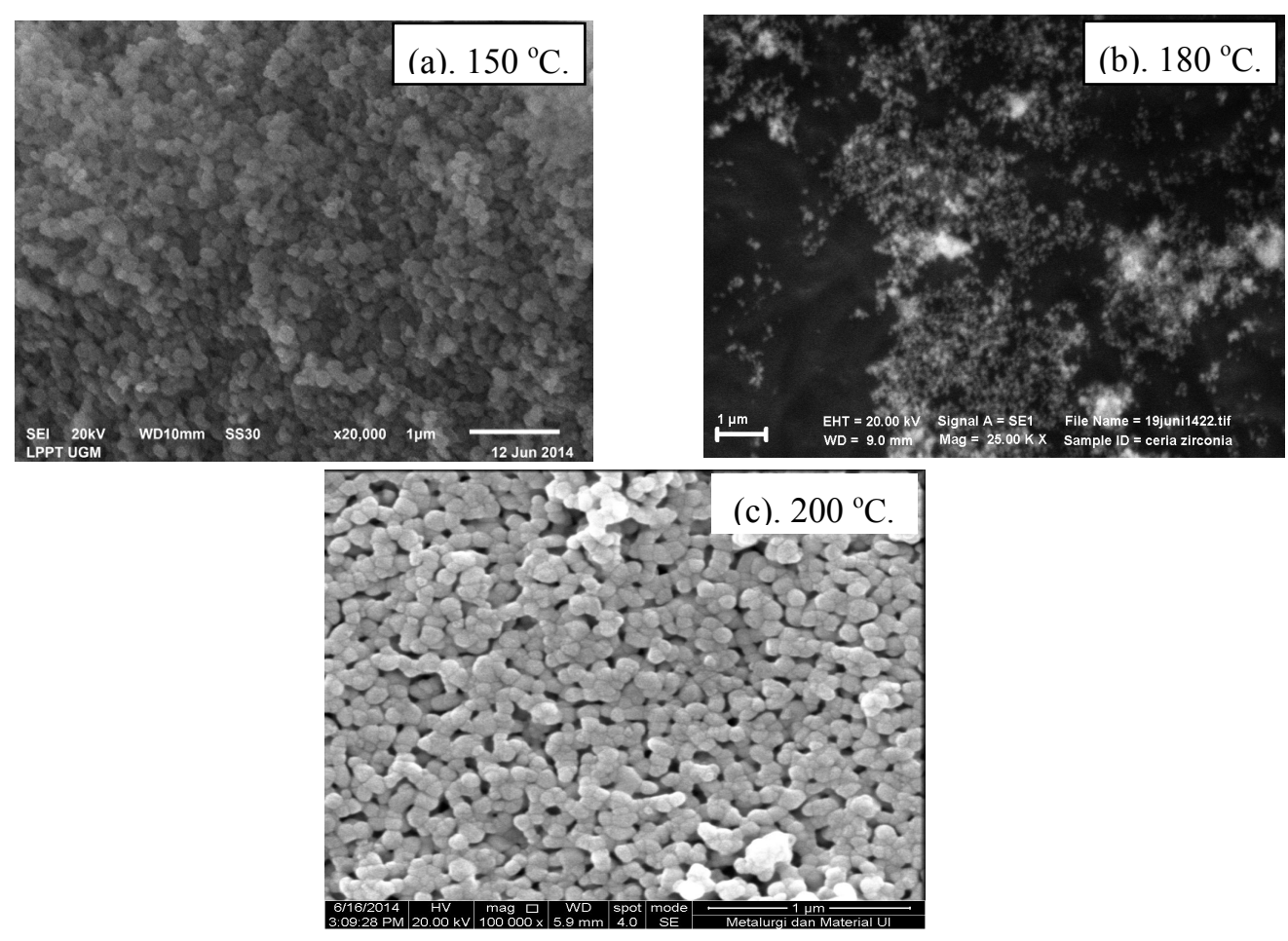

Figure 1. SEM image of $\mathrm{Ce}\left(\mathrm{NO}_{3}\right)_{3}$ and $\left(\mathrm{ZrO}\left(\mathrm{NO}_{3}\right)_{2}\right.$ mixed oxides after hydrothermal treatment at (a) 150, (b) 180 , and (c) $200^{\circ} \mathrm{C}$, respectively

The XRD patterns of calcined powder from ceria-zirconia mixed oxides after treatment by hydrothermal at various reaction temperature are shown in Figure 2.

Figure 3 shows the result of FTIR spectra for calcined powder of ceria-zirconia mixed oxides from $\mathrm{ZrO}\left(\mathrm{NO}_{3}\right)_{2}+$ $\mathrm{Ce}\left(\mathrm{NO}_{3}\right)_{3}$ after hydrothermal treatment at temperatures of (a) 150 , (b) 180 , and (c) $200^{\circ} \mathrm{C}$, respectively.

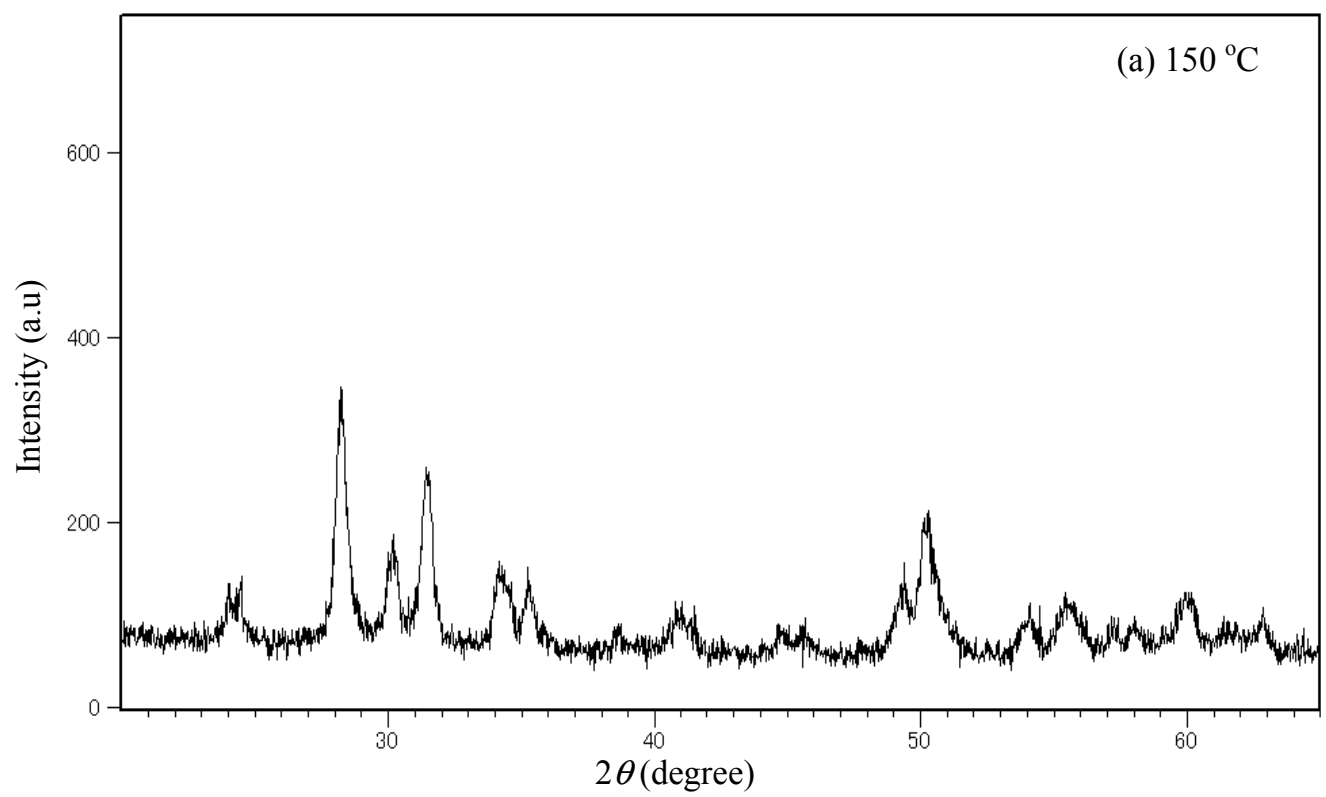



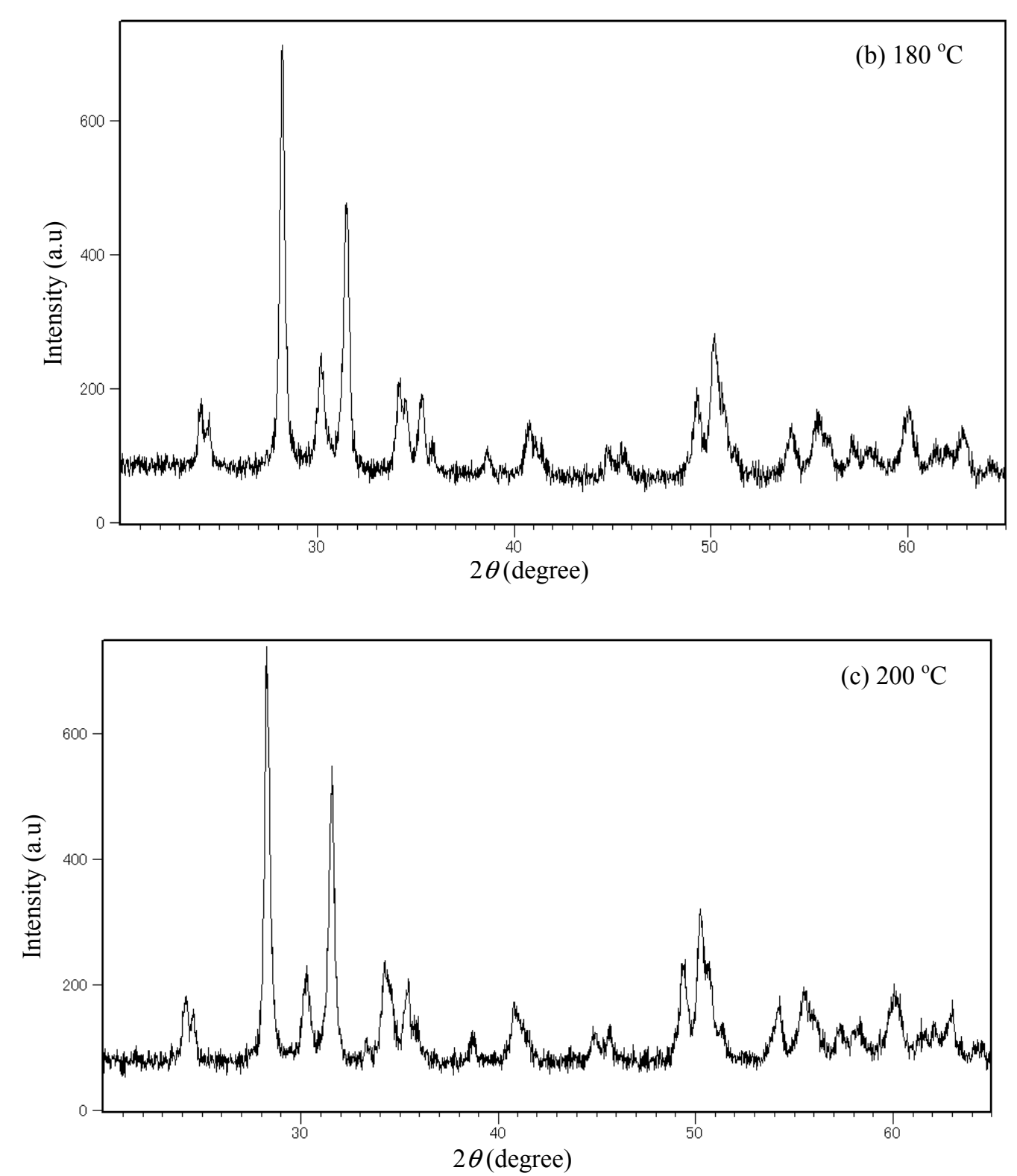

Figure 2. XRD patterns of $\mathrm{Ce}\left(\mathrm{NO}_{3}\right)_{3}$ and $\left(\mathrm{ZrO}\left(\mathrm{NO}_{3}\right)_{2}\right.$ mixed oxides after hydrothermal treatment at (a) 150, (b) 180 , and (c) $200{ }^{\circ} \mathrm{C}$, respectively.

\section{Discussion}

Based on the result of Figure 1, the particles produced at 150,180 , and $200^{\circ} \mathrm{C}$ were sphere shaped particles with smooth morphology. In this work, the particle diameters of calcined powder were determined by using particle size analyzer (PSA). The size of particle diameters were 35,61 , and $31 \mathrm{~nm}$ on average for reactions temperature 150,180 , and $200^{\circ} \mathrm{C}$, respectively. The smallest particles size was found when the reaction was carried out at $200^{\circ} \mathrm{C}$. In general, the increasing temperature in hydrothermal process gave positive influence on the structural characteristics and will enhance the nucleation rate and linear growth rate of particles production. As a result, the size of particles became larger and polydispersity was also slightly improved by the hydrothermal process (Cabuil et al., 2011). 


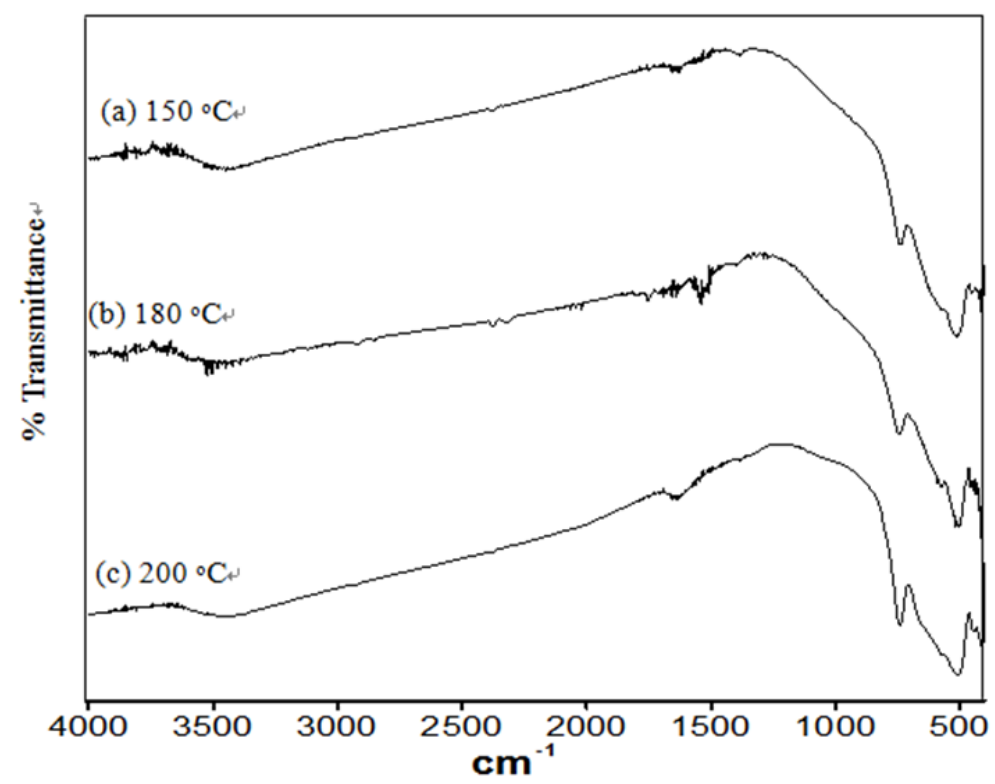

Figure 3. FTIR spectrum of $\mathrm{Ce}\left(\mathrm{NO}_{3}\right)_{3}$ and $\left(\mathrm{ZrO}\left(\mathrm{NO}_{3}\right)_{2}\right.$ mixed oxides after hydrothermal treatment at (a) 150, (b) 180 , and (c) $200{ }^{\circ} \mathrm{C}$, respectively

$\mathrm{XRD}$ is a powerful method for the study of nanomaterials, especially to characterize crystallographic structure for bulk, nano and thin film materials. In Figure 2, the diffraction lines at $2 \theta=28.25^{\circ}, 34.20^{\circ}, 49.30^{\circ}$, and $59.07^{\circ}$ correspond to the ceria-zirconia mixed oxide. These figures also indicated that the diffraction patterns of ceria-zirconia mixed oxide powder are uniformly distributed in the structure to form a homogeneous solid solution. Under hydrothermal conditions, an increase in temperature will increase both the nucleation rate and the linear growth rate, hence, the crystallinity of the samples normally increases in time. With the same reaction time, at higher temperature leads to the crystallization of more dense products. Therefore, as shown in Figure 2, higher synthesis temperatures resulted in higher peak intensities while lower temperatures resulted in lower peak intensities.

Based on FTIR spectra in Figure 3, it clearly exhibited that the residual water and hydroxyl groups were detected with a large band around $3500 \mathrm{~cm}^{-1}$, corresponding to the stretching vibration of the hydroxyl groups (Zaki et al., 2001). These stretching frequencies also indicated OH-groups are consisted type I (terminal, $-\mathrm{OH}$ ), II (bridging, $=\mathrm{OH}$ ), and III (multi-centered, $=\mathrm{OH}$ ). The bands at around $1640 \mathrm{~cm}^{-1}$ corresponds to $\mathrm{H}_{2} \mathrm{O}$ bending vibration and at around $1390 \mathrm{~cm}^{-1}$ is because of $\mathrm{Ce}-\mathrm{OH}$ stretching vibration. These bands are also assigned to bronsted acid sites, therefore both sites exist on all calcined powder samples (Neto and Schmal, 2013). The major features in the spectra of FTIR are around 740 and $540 \mathrm{~cm}^{-1}$ regions. These bands were probably because of the stretching vibration of metal oxide bonds. Generally, the transverse mode and the longitudinal component associated with the movements of oxide ions occurred at $400-650 \mathrm{~cm}^{-1}$. In the case of cerium-oxygen bonds, the bands at around $740 \mathrm{~cm}^{-1}$ has been observed. At the region $540 \mathrm{~cm}^{-1}$ which assigned to zirconia oxide bonds was also clearly observed. Damyanova et al., (Damyanova et al., 2008) found that the IR active mode in the $600-650 \mathrm{~cm}^{-1}$ range is caused by asymmetrically coupled asymmetric $\mathrm{Zr}-\mathrm{O}-\mathrm{Zr}$ stretching, and the mode arising from the symmetric $\mathrm{Zr}-\mathrm{O}-\mathrm{Zr}$ stretching is revealed in the $400-500 \mathrm{~cm}^{-1}$ region. As shown in the Figure 3, the spectral characteristics of the calcined powder from ceria-zirconia mixed oxides from $\mathrm{ZrO}\left(\mathrm{NO}_{3}\right)_{2}+\mathrm{Ce}\left(\mathrm{NO}_{3}\right)_{3}$ are essentially the same. This shows the three kinds of calcined powder have the similar functional group after hydrothermal treatment. It showed that after hydrothermal treatment, the solid solution phase is formed and a distortion of the unit cell in ceria-zirconia mixed oxides occurs.

In the conclusion, the hydrothermal synthesis of ceria-zirconia mixed oxides at temperatures of $150-200^{\circ} \mathrm{C}$ and pressure of $5 \mathrm{MPa}$ in batch systems was successfully conducted. The results showed that the particles formed were sphere shaped particles with smooth morphology and the size of particle diameters were 35, 61, and $31 \mathrm{~nm}$ on average for reactions temperatures of 150,180 , and $200^{\circ} \mathrm{C}$, respectively. The XRD pattern indicated that ceria-zirconia mixed oxides powder are uniformly distributed in the structure to form a homogeneous solid solution. Based on these results, it is proposed that hydrothermal synthesis is applicable to synthesize other type of metal composites. 


\section{Acknowledgments}

This research was supported by a grant from Directorate General of Higher Education, Ministry of Education and Art of Indonesia through a research grant Desentralisasi - Penelitian Unggulan Perguruan Tinggi contract no. 016457.8/IT2.7/PN.01.00/2014, and collaborated with Department of Chemical Engineering Nagoya University Japan.

\section{References}

Abdollahzadeh-Ghom, S., Zamani, C., Andreu, T., Epifani, M., \& Morante, J. R. (2011). Improvement of oxygen storage capacity using mesoporous ceria-zirconia solid solutions. Applied Catalysis B: Environmental, 108-109(0), 32-38. http://dx.doi.org/10.1016/j.apcatb.2011.07.038

Byrappa, K., \& Yoshimura, M. (2001). Handbook of Hydrothermal Technology - A Technology for Crystal Growth and Materials Processing (pp. 1-52), New York: William Andrew Publishing.

Cabuil, V., Dupuis, V., Talbot, D., \& Neveu, S. (2011). Ionic magnetic fluid based on cobalt ferrite nanoparticles: Influence of hydrothermal treatment on the nanoparticle size. Journal of Magnetism and Magnetic Materials, 323(10), 1238-1241. http://dx.doi.org/10.1016/j.jmmm.2010.11.013

Damyanova, S., Pawelec, B., Arishtirova, K., Huerta, M. V. M., \& Fierro, J. L. G. (2008). Study of the surface and redox properties of ceria-zirconia oxides. Applied Catalysis A: General, 337(1), 86-96. http://dx.doi.org/10.1016/j.apcata.2007.12.005

Lee, B. H., Nakayama, T., Tokoi, Y., Suzuki, T., \& Niihara, K. (2011). Synthesis of $\mathrm{CeO}_{2} / \mathrm{TiO}_{2}$ nanoparticles by laser ablation of Ti target in cerium (III) nitrate hexahydrate $(\mathrm{Ce}(\mathrm{NO}) 3 \cdot 6 \mathrm{H} 2 \mathrm{O})$ aqueous solution. Journal of Alloys and Compounds, 509(4), 1231-1235. http://dx.doi.org/10.1016/j.jallcom.2010.09.197

Neto, R. C. R., \& Schmal, M. (2013). Synthesis of $\mathrm{CeO}_{2}$ and $\mathrm{CeZrO}_{2}$ mixed oxide nanostructured catalysts for the iso-syntheses reaction. Applied Catalysis A: General, 450(0), 131-142. http://dx.doi.org/10.1016/j.apcata.2012.10.002

Raju, V., Jaenicke, S., \& Chuah, G. K. (2009). Effect of hydrothermal treatment and silica on thermal stability and oxygen storage capacity of ceria-zirconia. Applied Catalysis B: Environmental, 91(1-2), 92-100. http://dx.doi.org/10.1016/j.apcatb.2009.05.010

Sun, C., Li, H., \& Chen, L. (2012). Nanostructured ceria-based materials: synthesis, properties, and applications. Energy \& Environmental Science, 5(9), 8475-8505. http://dx.doi.org/10.1039/c2ee22310d

Wang, G., Mu, Q., Chen, T., \& Wang, Y. (2010). Synthesis, characterization and photoluminescence of $\mathrm{CeO}_{2}$ nanoparticles by a facile method at room temperature. Journal of Alloys and Compounds, 493(1-2), 202-207. http://dx.doi.org/10.1016/j.jallcom.2009.12.053

Yang, Q., Lu, Z., \& Liu, J., et al. (2013). Metal oxide and hydroxide nanoarrays: Hydrothermal synthesis and applications as supercapacitors and nanocatalysts. Progress in Natural Science: Materials International, 23(4), 351-366. http://dx.doi.org/10.1016/j.pnsc.2013.06.015

Yu, T., Lim, B., \& Xia, Y. (2010). Aqueous-Phase Synthesis of Single-Crystal Ceria Nanosheets. Angewandte Chemie International Edition, 49(26), 4484-4487. http://dx.doi.org/10.1002/anie.201001521

Yuan, Q., Duan, H. H., \& Li, L. L., et al. (2010). Homogeneously Dispersed Ceria Nanocatalyst Stabilized with

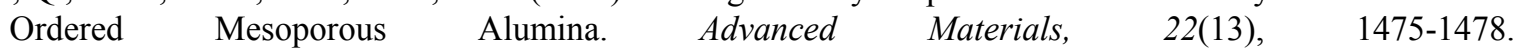
http://dx.doi.org/10.1002/adma.200904223

Zaki, M. I., Hasan, M. A., Al-Sagheer, F. A., \& Pasupulety, L. (2001). In situ FTIR spectra of pyridine adsorbed on $\mathrm{SiO}_{2}-\mathrm{Al}_{2} \mathrm{O}_{3}, \mathrm{TiO}_{2}, \mathrm{ZrO}_{2}$ and $\mathrm{CeO}_{2}$ : general considerations for the identification of acid sites on surfaces of finely divided metal oxides. Colloids and Surfaces A: Physicochemical and Engineering Aspects, 190(3), 261-274. http://dx.doi.org/10.1016/S0927-7757(01)00690-2

Zhu, Z., \& He, D. (2008). CO hydrogenation to iso-C4 hydrocarbons over $\mathrm{CeO}_{2}-\mathrm{TiO}_{2}$ catalysts. Fuel, 87(10-11), 2229-2235. http://dx.doi.org/10.1016/j.fuel.2007.10.029

\section{Copyrights}

Copyright for this article is retained by the author(s), with first publication rights granted to the journal.

This is an open-access article distributed under the terms and conditions of the Creative Commons Attribution license (http://creativecommons.org/licenses/by/3.0/). 